\title{
MAPRI, José; BLANES, Ruy; GIUMBELLI, Emerson; WILSON, Erin (Ed.). Secularisms in a postsecular age?: religiosities and subjectivities in comparative perspective. Cham: Palgrave Macmillian, 2017.300 p.
}

\author{
Adriano Santos Godoy* \\ *Universidade Estadual de Campinas - Campinas, SP, Brasil \\ Doutorando em Antropologia Social (bolsista Fapesp) \\ adrianosgodoy@gmail.com
}


O que se tornou o secularismo com a virada pós-secular? É essa a pergunta que norteia os organizadores da coletânea. Há muito tempo o secularismo pauta os debates públicos e acadêmicos sobre o papel e o lugar da religião na contemporaneidade, mas o que se percebe atualmente é que ele não só deixou de ser a única opção viável, como também sua eficácia política passou a ser questionada.

Aliás, a própria concepção do que é o secularismo, e suas frentes de ação e reação, nunca foi uma unanimidade. Sejam as considerações de Jurgen Habermas a respeito da esfera pública ou a abordagem de Charles Taylor enquanto ideal de modernidade, os organizadores indicam que as teorizações sobre o secularismo tendem a obscurecer as suas dimensões empíricas.

Com a constatação de que é impossível uma única definição do que seria o secularismo, uma das preocupações dos organizadores é justamente entender a pluralidade de secularismos existentes pelo seu viés mais prático. Apostando na proposta de Talal Asad e Saba Mahmood, as referências mais recorrentes, o secularismo é apontado como um projeto normativo e ideológico do liberalismo político para enquadrar a religião como incompatível com a vida pública. Como Asad e Mahmood indicam, a perversidade dessa ideologia ser centrada na tradição cristã europeia está na exclusão de religiosidades outras, como o islamismo, que consequentemente passam a ser vistas como irracionais ou perigosas.

Essa premissa, contudo, longe de resumir a discussão é apenas o ponto de partida para as análises mais profundas e específicas. Seja em Habermas (2008), Taylor (2007), Asad (2003) ou Mahmood (2015), os organizadores dessa coletânea questionam a falta de espaço para as subjetividades dos sujeitos envolvidos. Afinal, em quais locais, em quais contextos e com quais sujeitos esse secularismo pode ser percebido? Em outras palavras, não só como o secularismo é construído teoricamente, mas principalmente como ele é praticado no cotidiano, em subjetividades e em casos específicos em que se manifesta e se constrói enquanto relação.

Com uma equipe majoritária de autores antropólogos, a etnografia surge como o meio propício para a abordagem. E é nesse ponto que se pode ressaltar o diferencial da coletânea e a contribuição mais significativa que ela traz: sem abrir mão de um levantamento bibliográfico denso e aprofundado do tema, tem como propósito contrapor situações etnográficas das mais distintas, mostrar onde e como os processos de secularização são experienciados e negociados. 
A questão do islã no Ocidente, que norteia grande parte desse campo de discussão, não deixa de aparecer, mas de maneira mais nuançada. Isso fica claro no capítulo oito, de autoria de Verkaaik e Arab, que ao pesquisarem a construção de mesquitas na Holanda conseguem demonstrar que o secularismo com base constitucional pode ser mais vantajoso, política e religiosamente aos muçulmanos, do que a opção de um secularismo culturalista. Os agentes estatais holandeses, ao agir em nome da lei, conseguem driblar a islamofobia crescente na população.

Situação essa quase oposta à da vizinha Bélgica, abordada no capítulo dois, em que Maskens demonstra os pormenores rotineiros de uma repartição pública na qual, em nome da neutralidade burocrática, os agentes estatais proíbem casamentos que julgam ser de conveniência, entre belgas e não europeus, o que resulta em um controle migratório, descaradamente voltado para populações islâmicas, que nos moldes secularizantes são julgadas como insuficientemente modernas para habitar aquele país. Longe de ser homogênea, como demonstra Van den Brandt no capítulo seis, a população belga adepta ao islamismo se organiza em ONGs, para que consiga demonstrar suas demandas políticas como membro daquela sociedade civil usando de argumentos e pautas consideradas secularizadas e não religiosas.

As políticas de resistência islâmica também são abordadas por Delgado, no capítulo cinco, ao pesquisar diversos e distintos grupos de jovens espanhóis empenhados em desconstruir a imagem negativa do islamismo relacionado ao terrorismo. Nesse contexto o corpo passa a ser o campo de tensão e disputa secularista, sendo que para uns a resistência ao preconceito está em reafirmar a corporalidade islâmica, enquanto para outros está no dever de a amenizar aos padrões espanhóis. No mesmo caminho vai o capítulo quatro, no qual Martín-Sáiz demonstra como o corpo de espanhóis muçulmanos se torna o último lugar possível de expressão religiosa, com o avançar de leis secularizantes que coíbem espaços destinados ao culto.

Outro movimento importante do livro é levar a discussão da secularização para além da questão do islamismo na Europa, e de modo comparativo perceber as especificidades e os encontros nos contextos latino-americanos. Nesse sentido, nas trilhas da secularização, vários capítulos da coletânea conseguem abordar esse tema em locais pouco óbvios, e tão relevantes quanto, indo além dos contextos euro-americanos aos quais essa problemática é comumente 
associada. Birman é quem dá o maior passo nessa direção, no capítulo nove, ao afirmar que no Brasil o outro a ser domesticado pelo Estado não é o muçulmano, e sim a população negra e indígena. Ao acompanhar a invasão militar das favelas cariocas, demonstra como o processo civilizador brasileiro é uma constante guerra aos pobres pelo secular e pelo religioso, que não podem ser compreendidos apenas pelo viés da crença.

O capítulo três é bastante emblemático, ao trazer a discussão do secularismo para Cuba, um Estado ateísta. Panagiotopoulos remonta a história da ilha e demonstra como a religiosidade afro-cubana geralmente é indiferente ao processo de secularização, amplamente fomentado pelo Estado, justamente por não demonstrar publicamente interesses políticos.

Situação essa contrastante com a brasileira, como bem demonstra Montero no capítulo dez. No Brasil, a secularização surge com o advento da República, e desde então todas as Constituições tiveram que lidar com a liberdade de crença, em um país que por muito tempo teve o catolicismo como religião oficial. Constantemente coibidas, as religiosidades afro-brasileiras se ancoram na tolerância, a palavra-chave do secularismo nacional para o embate com o catolicismo e o pentecostalismo.

A tentativa de controle do pentecostalismo também aparece na Argentina, e, no capítulo treze, Frigeiro aponta como as restrições espaciais a esse grupo religioso estão intimamente relacionadas a um ideal secularizante de branquitude europeia, ancorado no catolicismo, e que normatiza os espaços públicos em Buenos Aires. Já o catolicismo argentino é abordado por Morello, no capítulo onze, no qual demonstra como no decorrer do tempo a identidade católica ficou mais institucionalmente independente. Para o autor, a secularização latino-americana se concretizou pela desterritorialização institucional da Igreja Católica, sem que a população deixasse de praticar publicamente uma religiosidade mais individualizada.

Como ficou claro até aqui, ao abordar contextos tão diferenciados, a coletânea consegue manter uma coerência argumentativa que transpassa as especificidades políticas e religiosas entre a Europa e a América Latina, e assim contribui com uma abordagem diferenciada do pós-secular. Isso fica ainda mais evidente com o capítulo sete, no qual Giumbelli e Toniol se propõem a entender como a presença da espiritualidade, uma categoria moderna e ocidental, se transforma em política pública de saúde no Brasil, e assim configura 
o lugar da religião nos hospitais secularizados. Situação distinta de Portugal, abordada no capítulo doze, em que Bernardo aponta o embate entre a biomedicina e a religião, também no ambiente hospitalar, e quais seriam as táticas de racionalização e sobrevivência dos capelães para justificar o seu contínuo trânsito entre o secular e o religioso.

Ao complexificar a secularidade pelo viés comparativo e empírico, essa coletânea consegue apreender as nuances do que seria o espaço público, já que o Estado e a religião nunca são tratados de forma homogênea. Como vimos, podem ir da rua até um hospital passando pelo parlamento. Por fim, vale ressaltar, a iniciativa de colocar a América Latina nesse debate passa além das etnografias e vai até a própria língua. A escolha da publicação em inglês, em uma coletânea em que nenhum autor está vinculado a instituições anglófonas, é bem-vinda e necessária para ampliar qualitativamente esse debate.

\section{Referências}

ASAD, T. Formations of the secular: Christianity, Islam and modernity. Stanford: Stanford University Press, 2003.

HABERMAS, J. Notes on post-secular society. New Perspectives Quarterly, v. 25, n. 4, p. 17-29, 2008.

MAHMOOD, S. Religious difference in a secular age: a minority report. Princeton: Princeton University Press, 2015.

TAYLOR, C. A secular age. Cambridge: The Belknap Press, 2007. 